\title{
Hyperuricaemia in hypertension: role of alcohol
}

\author{
LAWRENCE E RAMSAY
}

British Medical fournal, 1979, 1, 653-654

\section{Summary and conclusions}

Hyperuricaemia was present in 18 out of 73 men with untreated mild hypertension and was related significantly to alcohol intake, serum aspartate transaminase activity, and obesity. In the whole group the mean serum urate concentration correlated highly significantly with alcohol intake and activities of serum aspartate and alanine transferases but not with ponderal index, serum creatinine concentration, age, or blood pressure.

Hypertension and hyperuricaemia are related at least in part through their common association with frequent alcohol use. A serum urate concentration exceeding 0.5 $\mathrm{mmol} / 1(8.4 \mathrm{mg} / 100 \mathrm{ml})$ in a man with untreated hypertension is highly suggestive of heavy alcohol consumption. There was no evidence that hyperuricaemia had a deleterious effect on renal function.

\section{Introduction}

Hyperuricaemia is present in $26-33^{\circ}$ of patients with untreated hypertension ${ }^{1-3}$ and is largely unexplained. It is related in part to a reduced glomerular filtration rate ${ }^{1-5}$ but the renal clearance of urate is disproportionately low. ${ }^{23}$ Serum urate concentrations were increased with body weight in one study ${ }^{4}$ but not related to age. ${ }^{15}$ Some studies have shown an association with the severity of hypertension, ${ }^{14}$ whereas others have not. ${ }^{25}$ Concern has been expressed that hyperuricaemia may contribute to renal impairment in hypertension. ${ }^{3}$ Alcohol is a recognised cause of hyperuricaemia ${ }^{6} 7$ and is also associated with hypertension. ${ }^{8-10}$ I describe the relation of serum urate values to alcohol consumption in untreated hypertensive men.

\section{Methods}

In the Glasgow Blood Pressure Clinic clinical information on all patients is recorded in a standard manner and stored in a computer. ${ }^{11}$ During 1975-6 all patients attending one hospital for their initial visit or yearly review had their serum urate, creatinine, and cholesterol concentrations and activities of serum aspartate and alanine aminotransferases (serum AST (SGOT) and serum ALT (SGPT)) measured routinely by automated methods (Technicon 18/60 screen). A computer print-out of the results was the basis of this study. The form completed on the date of blood testing was examined, and patients receiving drugs excluded. Body weight, blood pressure, and age of the untreated patients were obtained from the form, and height, smoking habit, and alcohol intake from the document completed at the first clinic attendance. Alcohol intake was assessed by a scoring system $(0=$ nil, $1=$ occasional, 2 =frequent, $3=$ heavy) that correlates with biochemical liver dysfunction. ${ }^{912}$ Women rarely admitted to more than occasional alcohol consumption ${ }^{9}$ and were excluded from the study. Ponderal index was calculated as height (inches) 3 , weight (Ib). Serum AST and ALT activities were log transformed to normalise

Western Infirmary, Glasgow, and The Glasgow Blood Pressure Clinic LAWRENCE E RAMSAY, MR, MRCP, lecturer in medicine (now consultant physician and associate in medicine, university department of therapeutics, Hallamshire Hospital, Sheffield S10 2JF

their distributions. Statistical methods used were the $\chi^{2}$ test with Yates's correction when appropriate, Student's $t$ test for unpaired variables, and product moment correlations.

\section{Results}

Out of 73 men with untreated hypertension, $18(25 \%)$ had serum urate concentrations exceeding the upper limit of normal in the laboratory $(0.43 \mathrm{mmol} / 1(7.2 \mathrm{mg} / 100 \mathrm{ml}))$. These men (table I) had significantly higher alcohol consumption and log serum AST values and significantly lower ponderal indices-that is, they were more obese-than the normouricaemic group. The groups did not differ in age, serum creatinine concentration, blood pressure, smoking habit, or serum cholesterol concentration. Hyperuricaemia was related significantly to serum AST values above the normal range $\left(\chi={ }_{1}^{2} 6.6\right.$; $\mathrm{P}<0.02)$. Six men $(8 \%)$ had serum urate concentrations above 0.5 $\mathrm{mmol} / 1(8.4 \mathrm{mg} / 100 \mathrm{ml})$. Five were heavy drinkers, and the sixth a frequent drinker $\left(\chi_{1}^{2}=13.1 ; P<0.001\right)$; this man had abnormal serum transaminase values. Serum urate concentrations correlated with alcohol score $(\mathrm{r}=+0.27 ; \mathrm{P}<0.02), \log$ serum ALT activity $(\mathrm{r}=+0.41 ; \mathrm{P}<0.001)$, and $\log$ serum AST activity $(\mathrm{r}=+0.44$; $\mathrm{P}<0.001)$ but not with any other variable, although the correlation with ponderal index approached significance $(r=-0.20 ; P<0.1)$ (table II).

TABLE I-Clinical and laboratory details of hypertensive men with hyperuricaemia and who were normouricaemic. Mean values expressed $\pm S D$

\begin{tabular}{|c|c|c|c|c|}
\hline & & & $\begin{array}{c}\text { Hyperuricaemic } \\
\operatorname{men}(n=18)\end{array}$ & $\begin{array}{c}\text { Normouricaemic } \\
\operatorname{men}(n=55)\end{array}$ \\
\hline \multicolumn{2}{|c|}{ Serum urate $(\mathrm{mmol} / \mathrm{l})($ normal $\leqslant 0.43)$} & . & $0.50 \pm 0.07$ & $0.35 \pm 0.06$ \\
\hline Age (years) $\quad . \quad \ldots$ & .. & .. & $44 \pm 14$ & $45 \pm 13$ \\
\hline Ponderal index* & . & $\cdots$ & $11.8 \pm 0.5$ & $12 \cdot 1 \pm 0.5$ \\
\hline Serum creatinine $(\mu \mathrm{mol} / 1) \quad \ldots$ & . & $\cdots$ & $88 \pm 11$ & $90 \pm 20$ \\
\hline $\mathbf{B P}(\mathrm{mm} \mathrm{Hg})\left\{\begin{array}{l}\text { Systolic } \\
\text { Diastolic }\end{array}\right.$ & . & . & $168 \pm 29$ & $166 \pm 21$ \\
\hline No of non-smokers $\ldots$ & . & $\because$ & $102 \frac{ \pm}{5}$ & $\begin{array}{c}98 \pm 13 \\
21\end{array}$ \\
\hline Serum cholesterol $(\mathrm{mmol} / 1) \ldots$ & $\because$ & $\therefore$ & $6 \cdot 5 \pm 1 \cdot 1$ & $6 \cdot 2 \pm 1.5$ \\
\hline Log serum ALT (IU/1) & . & . & $1.61 \pm 0.36$ & $1.44 \pm 0.31$ \\
\hline $\log _{\text {serum }}^{\text {AST }}\left(\mathrm{IU}_{\mathrm{Nil} / \text { occasional }}{ }^{+}\right.$ & . & . & $1.51 \div 0.37$ & $1 \cdot 35 \frac{1}{31} 0 \cdot 21$ \\
\hline \multirow{2}{*}{ Alcohol use +} & $\because$ & $\cdots$ & 6 & 17 \\
\hline & 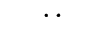 & .. & 7 & 7 \\
\hline
\end{tabular}

${ }^{*} t=2.09 ; \mathrm{DF}=71 ; \mathrm{P}<0.05 . \quad+t=2.22 ; \mathrm{DF}=66 ; \mathrm{P}<0.05 . \quad+\chi^{2}=7.11 ; \mathrm{DF}=2$; $\mathrm{P}<0.05$. Conversion: SI to traditional units-Serum urate: $1 \mathrm{mmol} / 1 \approx 17 \mathrm{mg} / 100 \mathrm{ml}$.
Serum creatinine: $1 \mu \mathrm{mol} / 1 \approx 0.01 \mathrm{mg} / 100 \mathrm{ml}$. Serum cholesterol: $1 \mathrm{mmol} / 1 \approx 38 \cdot 6$ $\mathrm{mg} 100 \mathrm{ml}$.

TABLE II-Correlations of serum urate concentrations with other variables in 73 hypertensive men

\begin{tabular}{|c|c|c|c|c|c|c|c|}
\hline & $\begin{array}{l}\text { Alcohol } \\
\text { score }\end{array}$ & $\begin{array}{l}\log \\
\text { serum } \\
\text { ALT }\end{array}$ & $\begin{array}{l}\text { Log } \\
\text { serum } \\
\text { AST }\end{array}$ & $\begin{array}{l}\text { Ponderal } \\
\text { index }\end{array}$ & Age & $\begin{array}{c}\text { Diastolic } \\
\text { BP }\end{array}$ & $\underset{\text { creatinine }}{\text { Serum }}$ \\
\hline$\stackrel{r}{\mathrm{P}}$ & $\begin{array}{l}+0.27 \\
<0.02\end{array}$ & $\begin{array}{l}+0.41 \\
<0.001\end{array}$ & $\begin{array}{l}+0.44 \\
<0.001\end{array}$ & $\begin{array}{c}-0.20 \\
<0.1\end{array}$ & $\begin{array}{l}-0.07 \\
\text { NS }\end{array}$ & $\begin{array}{c}+0.03 \\
\text { NS }\end{array}$ & $\begin{array}{l}+0.08 \\
\text { NS }\end{array}$ \\
\hline
\end{tabular}

$\mathrm{NS}=$ Not significant.

\section{Discussion}

I restricted the study to untreated patients because many antihypertensive drugs (diuretics, postganglionic adrenergic blockers, methyldopa, and $\beta$-adrenergic blockers) may alter the serum urate concentration. This resulted in the selection of men with mild and generally uncomplicated hypertension, who were not representative of all patients attending the clinic. Nevertheless, the prevalence of hyperuricaemia $\left(25^{\circ} \%\right.$ ) was similar to that reported $\left(26-33^{\circ}{ }_{0}\right) .^{1-3}$ 
Men with hyperuricaemia consumed more alcohol and had higher serum AST values than those with normal serum urate concentrations, and in the whole group the serum urate concentrations correlated highly significantly with the alcohol score and both serum transaminase values. In men attending this clinic serum AST activity correlates with alcohol scores independent of age, weight, blood pressure, or drug treatment ${ }^{912}$ and is therefore a specific (albeit imprecise) marker of alcohol intake. The higher correlations of serum urate value with the serum transaminase activities may reflect the imprecision of the alcohol scoring system or may have arisen because the biochemical variables were measured simultaneously. The alcohol scores were determined on entry to the clinic, which was often months and sometimes years before the serum urate concentrations was measured. Alcohol scores were ascribed to patients without knowledge of the serum urate value and without the present hypothesis in mind, so that bias cannot explain the findings. High alcohol consumption was responsible for a quarter of the serum urate values above $0.43 \mathrm{mmol} / 1(7.2$ $\mathrm{mg} / 100 \mathrm{ml})$ and about $80^{\circ}{ }_{0}$ of those above $0.5 \mathrm{mmol} / 1(8.4$ $\mathrm{mg} / 100 \mathrm{ml}$ ) in these hypertensive men.

My findings confirm an association between obesity and hyperuricaemia in hypertension, ${ }^{4}$ although the correlation of the serum urate concentration with ponderal index was not significant in the whole group. Relations between raised serum urate values and higher serum cholesterol concentrations ${ }^{23}$ or blood pressure ${ }^{14}$ were not confirmed, although the trends were in this direction (table I). Concentrations of serum creatinine and urate were not related, showing again that hyperuricaemia in hypertension is not merely a consequence of reduced glomerular filtration. ${ }^{2}{ }^{3}$ Also this observation does not support the suggestion that hyperuricaemia has an adverse effect on renal function. ${ }^{3}$ None of the men with more severe hyperuricaemia (mean value $0.57 \mathrm{mmol} / 1(9.6 \mathrm{mg} / 100 \mathrm{ml})$; mean age 44 years) had a raised serum creatinine concentration (mean $93 \mu \mathrm{mol} / 1 ; 1 \cdot 1 \mathrm{mg} / 100 \mathrm{ml}$ ).

The association between hyperuricaemia and hypertension has three possible explanations ${ }^{2}$ : hyperuricaemia may cause hypertension; hypertension may cause hyperuricaemia; or some factor may be common to both. My results suggest that it is due at least partly to a common association with alcohol. The mechanism linking alcohol and hypertension ${ }^{8-10}$ is unknown.
Alcohol causes hyperuricaemia by increasing the serum lactate concentration with a consequent reduction in the renal tubular secretion of urate." The renal tubular "defect" in urate handling in hypertension" might be explained thus, at least in some patients. A raised serum lactate concentration was found to be common in hypertensive patients ${ }^{313}$ and it was suggested that the reduced renal clearance of urate was related to this, ${ }^{3}$ although the evidence was not strong. In one study patients with essential hypertension had serum urate concentrations significantly higher than those with renal hypertension. ${ }^{4}$ If alcohol is an important determinant of the serum urate value in hypertension, as my findings suggest, alcohol may be related particularly to essential hypertension and not to renal hypertension. This would strengthen the possibility that alcohol may have a causal role in hypertension of unknown aetiology.

I am grateful to the many physicians in the Western Infirmary, Royal Infirmary, Stobhill Hospital, and Southern General Hospital, Glasgow, who collected the data on which this study was based, and to the many people concerned in the editing, data processing, and computing sections of the Glasgow Blood Pressure Clinic. The Glasgow Blood Pressure Clinic has received financial support from the Western Regional Hospital Board, the Board of Management of the Western Infirmary and Gartnavel Hospital, the Medical Research Council, Ciba Ltd, ICI Ltd, and Searle Ltd.

\section{References}

${ }^{1}$ Kinsey, D, et al, Circulation, 1961, 24, 972.

${ }^{2}$ Breckenridge, A, Lancet, 1966, 1, 15.

${ }^{3}$ Cannon, P J, et al, New England fournal of Medicine, 1966, 275, 457.

4 Wessels, F, et al, Medizinische Klinik, 1974, 69, 599.

${ }^{5}$ Bulpitt, C J, British Heart Fournal, 1975, 37, 1210

${ }^{6}$ Lieber, C S, et al, fournal of Clinical Investigation, 1962, 41, 1863.

7 Whitehead, T P, Clarke, C A, and Whitfield, A G W, Lancet, 1978, 1, 978.

${ }^{8}$ Klatsi:y, A L, et al, New England fournal of Medicine, 1977, 296, 1194.

- Ramsay, L E, Lancet, 1977, 2, 111 .

10 Beevers, D G, Lancet, 1977, 2, 114.

11 Glasgow Blood Pressure Clinic, fournal of the Royal College of Physicians of London, 1972, 7, 87.

12 Ramsay, L E, paper read to the Scottish Society of Physicians, 1977.

${ }^{13}$ Demartini, F E, et al, Science, 1965, 148, 1482.

(Accepted 10 Fanuary 1979)
ONE HUNDRED YEARS AGO A well-nourished infant aged seven months, nursed by a healthy wet nurse, was in perfect health till twelve o'clock on September 4th. She then suddenly screamed, and immediately afterwards became collapsed, pale, and cold. She was put into a warm bath, after which she lay quiet in the nurse's arms for an hour and a half, the bowels acting slightly once or twice. At $3 \mathrm{pm}$, the child had become warmer and was sleeping quietly, occasionally, however, waking up with a scream, and drawing up her legs with an expression of severe pain. She took the breast at intervals, and then vomited, without much effort, the whole or a portion of what she had swallowed. Nothing abnormal could be detected in the abdomen, and in the intervals between the paroxysms of pain, a casual observer would have thought the child in perfect health. A mixture containing nearly one minim of tincture of opium for a dose was given and retained; and the child was afterwards more quiet till $6 \mathrm{pm}$, when she passed two motions consisting of blood-stained mucus. She continued much in the same state during the evening, occasionally passing a small quantity of mucus after a paroxysm of pain. At $9 \mathrm{pm}$, she was seen by Dr Moore, and a large injection was proposed; but as Dr Gee was expected at $11 \mathrm{pm}$, it was decided to postpone all further treatment till his arrival. A distinct but ill-defined oval tumour, about an inch and a half in its longest diameter, could then be felt through the parietes, at a spot about two inches to the left of the umbilicus. A considerable quantity, perhaps a drachm, of dark blood came away. It was determined to distend the large intestine with thin gruel. The child was, therefore, put thoroughly under the influence of chloroform and placed on a table, with the nates well raised on a pillow. The gruel was then slowly injected by means of a Higginson's syringe, the upper part of the nozzle being pressed firmly against the anus to prevent any from escaping. After a pint or more had been injected, the abdomen became somewhat tense, and the distended bowel could be felt like a hard rope an inch in diameter, across the upper part of the abdomen, almost as far as the right iliac region, and considerable force would have been required to inject any more of the fluid. When the nozzle of the syringe was removed, a portion of the gruel escaped, and soon afterwards, a much larger quantity. The child slept at intervals during the night, and took the breast well, and there was no vomiting nor pain. Next morning, at $8 \mathrm{am}$, the skin was a little hot and the pulse a little quick, and one small healthy motion had been passed. The tumour which had been felt in the abdomen had now quite disappeared. At $1 \mathrm{pm}$, all the feverish symptoms were gone, and the child had passed a copious motion of a green colour, and there had been no symptom of pain or spasm. At $4 \mathrm{pm}$, she passed another copious motion of the same character. From this time, the child appeared in perfect health, but the motions retained their green and unhealthy appearance till September 8th, four days after the commencement of the attack.

The success which attended the means adopted for the recovery of this little patient was due, perhaps, first, to the chloroform, which, by allaying muscular spasm, and preventing any struggling on the part of the child, allowed the treatment to be efficiently carried out; then the injection of gruel was had recourse to early, before the intussusception could have extended far, or the invaginated bowel become congested and swollen; and lastly, the position of the child, lying on her back with the nates raised, favoured by gravitation the introduction of the fluid. (British Medical fournal, 1879.) 